\title{
Hemodialysis Vascular Access Dysfunction
}

\author{
Timmy Lee \\ Assistant Professor of Medicine \\ Department of Internal Medicine and Division of Nephrology and Hypertension, \\ University of Cincinnati and Veterans Affairs Medical Center, Cincinnati, OH; \\ United States of America
}

\section{Introduction}

A successful functioning vascular access is the "lifeline" for a hemodialysis patient. Hemodialysis vascular access dysfunction is a major cause of morbidity and mortality in hemodialysis patients ${ }^{1-3}$. Improving vascular access outcomes remains an ongoing challenge for nephrologists, vascular access surgeons, and interventionists. In arteriovenous fistulas (AVF) and grafts (AVG), the most common cause of this vascular access dysfunction is venous stenosis as a result of neointimal hyperplasia within the peri-anastomotic region (AVF) or at the graft-vein anastomosis (AVG) ${ }^{4,5}$. There have been few effective treatments to-date for venous neointimal hyperplasia in part because of the poor understanding of the pathogenesis of venous neointimal hyperplasia. Central venous catheters (CVC) are prone to frequent thrombosis and infection and the treatment of catheter-related bacteremia (CRB) remains on ongoing debate ${ }^{6-8}$. Therefore, this review will: (1) describe the pathology and pathophysiology of hemodialysis access stenosis in AVFs and AVGs, (2) discuss the pathogenesis of CRB and catheter thrombosis (3) discuss current and future novel therapies for treating venous neointimal hyperplasia, (4) discuss current strategies to treat CRB and catheter thrombosis, and (5) suggest future research areas in the field of hemodialysis vascular access dysfunction.

\subsection{Types of hemodialysis access}

Successful hemodialysis treatment requires access to the bloodstream to deliver a high enough blood flow to achieve an adequate dialysis dose. There are three primary types of hemodialysis vascular access to achieve this goal: (1) arteriovenous fistula, (2) arteriovenous graft, and (3) tunneled central venous catheter. Each type of access has unique advantages and individual problems.

\subsubsection{Arteriovenous fistula}

AVFs are the preferred vascular access for hemodialysis patients, because once mature and functional, they require fewer interventions to maintain patency and develop fewer infections compared to AVGs 9-13. However, AVFs have higher rates of nonmaturation and longer maturation times compared to AVGs, which may lead to prolonged periods of CVC dialysis 9,14,15. Recent reports from the United States have shown that up to $60 \%$ of AVFs never mature adequately to be successfully cannulated for dialysis 16 compared to 20-25 years ago where the nonmaturation rates in AVFs was approximately $10 \% 12$. 


\subsubsection{Arteriovenous graft}

Arteriovenous grafts (made from polytetrafluoroethylene, a synthetic fluoropolymer of tetrafluoroethylene) are advantageous because of short maturation time and relative ease to cannulation compared to AVFs 12,17-19. Until recently, AVGs were the most common access used in hemodialysis patients in the Unites States ${ }^{20}$. However, the main disadvantages of AVGs are development of recurrent venous stenosis, requiring frequent interventions to maintain patency, and graft infection 19,21-24.

\subsubsection{Tunneled central venous catheter}

Tunneled central venous catheters have the advantage of immediate use, multiple sites for insertion, and the ability to provide access for hemodialysis for a period of months, permitting time for AVF or AVG maturation, in patients who require immediate hemodialysis 19,25-28. However, the main disadvantages are the high risks of morbidity and mortality caused by infection 7,29-33, catheter thrombosis 19,34-37, and central venous stenosis $37-39$.

\section{Epidemiology and clinical significance of hemodialysis vascular access dysfunction}

\subsection{Epidemiology of hemodialysis vascular access}

Due to reduced AVF use and increased AVG (70\% in $\left.1993{ }^{40}\right)$ and catheter use in the United States from the mid-1980's-1990's, the National Kidney Foundation in 1997, in an effort to improve vascular access outcomes, published the first Kidney Disease Outcome Quality Initiative (K/DOQI) clinical practice guidelines for vascular access to optimize the care of vascular access in hemodialysis patients using evidenced and opinion-based guidelines ${ }^{41}$. Since these initial clinical practice guidelines have been published, we have seen the creation of the Fistula First Breakthrough Initiative (FFBI) ${ }^{42-45}$ and two more revised K/DOQI clinical practice guidelines and performance measures for vascular access 19,46, which have clearly impacted and improved hemodialysis vascular access management. The most recent report from the 2009 United States Renal Data System (USRDS) has showed an AVF prevalence of 50\% 47 , a marked improvement since 2004 (39\% AVF prevalence), 2000 (30\% AVF prevalence), and 1998 (26\% AVF prevalence) $)^{48}$ in the United States. In contrast, AVF prevalence in Europe and Japan, reported from the Dialysis Outcomes and Practice Patterns Study (DOPPS) has been historically much higher, ranging from $57-91 \% 20$.

While the K/DOQI guidelines and FFBI have clearly played an instrumental role in meeting the initial target goal of 50\% AVF prevalence (new goal $66 \% 19,42$ ), the prevalence of CVC use continues to remain between $20-30 \%$ in the United States ${ }^{42}$. Furthermore, this trend of increased catheter use has also been observed in other countries, such as Spain, France, Belgium, Germany, and Italy ${ }^{20}$. This is likely due to an increase in the number of AVFs that have failed to mature for dialysis use in recent years 14,16 .

\subsection{Clinical significance and economic implications of hemodialysis vascular access dysfunction}

When patients develop vascular access dysfunction, due to an immature AVF or thrombosed AVF or AVG, they are often consigned to CVC use for prolonged periods. Because dialysis with a catheter is associated with increased morbidity and mortality 49-55, CVC use has significant clinical implications such as increased risk of bacteremia which has been reported to occur at a frequency ranging from 2.5 to 5.5 episodes per 1000-catheter 
days 6,56 , increased risk of 1-year mortality 49 , and $60-70 \%$ higher risk of subsequent AVF failure 32,57 . The cost of treating one CVC-related bacteremia in the United States has been estimated to be as high as $\$ 45,000$ per episode with an average of $\$ 22,000$ per bacteremic episode 58 .

\section{Pathology and pathophysiologic mechanisms of hemodialysis vascular access dysfunction}

\subsection{Pathology of Hemodialysis Vascular Access Stenosis in AVF and AVG}

Venous stenosis that occurs in both AVFs and AVGs is primarily due to neointimal hyperplasia. Venous stenosis in AVGs most frequently arises from the development of aggressive neointimal hyperplasia, characterized by (a) the presence of alpha smooth muscle actin positive cells myofibroblasts, and microvessels within the neointima, (b) an abundance of extracellular matrix components, (c) angiogenesis (neovascularization) within the neointima and adventitia, (d) a macrophage layer lining the perigraft region, and (e) an increased expression of mediators and inflammatory cytokines such as TGF- $\beta$, PDGF, and endothelin within the media, neointima and adventitia ${ }^{59-64}$.

While the neointimal hyperplasia in AVFs is similar to AVGs in regards to pathogenesis, the venous stenosis that develops in AVFs is highly influenced by the capacity of the vein to vasodilitate and vascular injury from surgical technique 65 . In AVFs the two main etiologies of failure are an initial failure to mature (nonmaturation) and a subsequent (late) venous stenosis ${ }^{4}$. Similar to AVGs, venous neointimal hyperplasia in late AVF stenosis has been shown to be composed primarily of alpha smooth muscle actin positive cells, together with expression of mediators and cytokines such as TGF- $\beta$, PDGF, and endothelin within the media and intima of the vein 60,65 . However, recently, the lesion of AVF nonmaturation at 6 weeks after AVF creation has also been described to have significant neointimal hyperplasia 66 .

\subsection{Pathophysiologic mechanisms of neointimal hyperplasia formation in hemodialysis access dysfunction}

The pathogenesis of venous neointimal hyperplasia in AVG stenosis and late AVF stenosis has been well described and is commonly divided into upstream and downstream events 4 . Upstream events are characterized as the initial events and insults that are responsible for endothelial and smooth muscle cell injury, which leads to a cascade of mediators (downstream events) that regulate oxidative stress, endothelial dysfunction, and inflammation (eventually resulting in venous neointimal hyperplasia). Upstream events that are believed to contribute to the pathogenesis of neointimal hyperplasia include 4,62,67-70: (1) surgical trauma at the time of AV surgery, (2) hemodynamic shear stress at the veinartery or vein-graft anastomosis, (3) bioincompatability of the AVG, (4) vessel injury due to dialysis needle punctures, (5) uremia resulting in endothelial dysfunction, and (6) repeated angioplasties causing further endothelial injury. Downstream events represent the response to endothelial (vascular) injury from the upstream events, resulting in the migration of smooth muscle cells from the media to the intima and eventually the development of neointimal hyperplasia 65 .

The pathogenesis in AVFs that fail to mature (early failure) for dialysis, in contrast to AVG and late AVF failure, remains poorly understood. At a histological level early AVF failure is also characterized by aggressive neointimal hyperplasia in both animal and human models, seen as early as 1 month in animals ${ }^{63,71}$ and 3 months in humans ${ }^{64,66}$. The underlying factors 
(upstream events) which may contribute to early AVF failure, include 4,72-81: (1) small diameter sizes in the vein and artery, (2) surgical injury at the time AV fistula placement, (3) previous venipunctures, (4) development of accessory veins after surgery, (5) hemodynamic shear stress at the AV anastomosis, (6) a genetic predisposition to vascular constriction and neointimal hyperplasia, and (7) pre-existing venous neointimal hyperplasia.

The subsequent sections will focus on the downstream events and three main mechanisms responsible for neointimal hyperplasia such as oxidative stress, inflammation, endothelial dysfunction, and alternative origins of neointimal-derived cells.

\subsubsection{Oxidative stress}

Many of the upstream mechanisms above (particularly hemodynamic shear stress and angioplasty injury) have been documented to result in an increase in the production of free radicals and its downstream products nitrotyrosine and latter (peroxynitrate). The latter is a potent upregulator of the matrix metalloproteinases (MMPs) 82,83. MMPs are key enzymes that cause breakdown of extracellular matrix proteins such as collagen and elastin which facilitate the migration of vascular smooth muscle cells (VSMCs) in neointimal hyperplasia formation ${ }^{84}$. MMPs, paradoxically, have also been shown to facilitate a beneficial dilatation of the feeding artery (through degradation of the internal elastic laminae) in both rabbit and mouse AVF models 82,85. Experimental studies of AVGs have demonstrated a differential upregulation of MMP-2 at the graft-vein anastomosis, with early expression (9 days) in the adventitia and a later expression (19 days) within the intima, supporting the concept of cellular migration from the adventitia to the intima ${ }^{86}$. Furthermore, linkages between hemodynamic shear stress and the expression of oxidative stress markers and cytokines have also been described in a porcine model of AVG stenosis ${ }^{87}$. Clinical studies of stenotic and thrombotic AVGs and AVFs have also demonstrated an upregulation of MMPs 88, and have documented the co-localization of oxidative stress markers with inflammatory cytokines such as transforming growth factor-beta (TGF- $\beta$ ), and platelet-derived growth factor (PDGF), within the neointima of both stenotic AVGs and AVFs 60.

Heme-oxygenase-1 (HO-1) is an important enzyme pathway which has been shown to confer protective effects in the vascular endothelium and other organ systems through its anti-inflammatory, antioxidant, or antiproliferative actions and properties 89 . Experimental studies in AVFs have described an increase in both the magnitude of arteriovenous stenosis and the frequency of thrombosis following the creation of AVFs in HO-1 knock out mice (increased baseline oxidative stress) as compared to wild type animals ${ }^{90}$. Furthermore, in the HO-1 knockout mice, there was significant induction of MMP-9 expression in the vein at 1 week compared to wild type mice, suggesting that MMP expression in vascular tissue and its deleterious effects with regard to promoting cellular migration may in part be inhibited by HO-1. Clinical studies have demonstrated a higher frequency of AVF failure in patients with heme-oxygenase-1 (HO-1) gene polymorphisms with long GT repeats (resulting in increased oxidative stress) ${ }^{73}$.

\subsubsection{Inflammation}

ESRD is associated with a chronic inflammatory state, characterized by the elevation of circulating cytokines and chemokines ${ }^{91}$. This inflammation has been proposed to play an important role in the initiation and progression of atherosclerosis in ESRD, but may also play a significant role in vascular access stenosis. Support for this paradigm comes from 
recent work in which uremic mice developed a 2-3 fold greater magnitude of neointimal hyperplasia at the arteriovenous anastomosis as compared to non-uremic animals in a mouse model of AVF stenosis ${ }^{92}$, and a recent study which showed marked upregulation of monocyte chemoattractant protein-1 (MCP-1) in the venous segment of AVF compared to rats deficient in the MCP-1 gene ${ }^{93}$.

In clinical studies, possible linkages have described the presence of inflammatory cells (macrophages and lymphocytes), cytokines such as TGF- $\beta$ and insulin-like growth factor-1 (IGF-1) and the magnitude of neointimal hyperplasia and venous stenosis within stenotic AVFs ${ }^{94}$.

Local bioincompatability to synthetic polytetrafluoroethylene (PTFE) material in AVGs could also result in local inflammation ${ }^{95}$. In vitro studies have demonstrated that conditioned media obtained after the interaction of peripheral blood mononuclear cells (PBMCs) with PTFE graft material resulted in a significant upregulation of smooth muscle cell proliferation as compared to control media ${ }^{96}$. This proliferative response has been shown to be attenuated by tumor necrosis-alpha (TNF- $\alpha$ ) inhibitors ${ }^{96}$. Furthermore, the presence of macrophages that line PTFE graft material has been described in both experimental and clinical AVG stenosis with co-expression of inflammatory cytokines such as basic fibroblast growth factor (bFGF) 61,97 .

\subsubsection{Endothelial dysfunction}

An intact and functional endothelium is essential for the vein to properly respond to acute changes in blood flow that occurs after creation of AVFs and AVGs 98. Nitric oxide (NO) is an important mediator responsible for these transformations 99,100 . The presence of uremia in hemodialysis patients has been shown to exacerbate endothelial dysfunction, possibly through the pathways of inflammation and oxidative stress described above 101,102. In the specific context of vascular access stenosis, endothelial dysfunction is likely to be responsible for the development of pre-existing venous neointimal hyperplasia ${ }^{77-81}$, medial hypertrophy 77,81 and radial artery intima-media thickening ${ }^{103-105}$ that is present even before the creation of AVFs in uremic patients. Pre-existing arterial intima-media thickness has been correlated with future AVF dysfunction ${ }^{103}$. Recently, pre-existing venous neointimal hyperplasia has been linked to poor AVF maturation in a small clinical study 77 .

Asymmetrical dimethylarginine (ADMA) is an endogenous inhibitor of NO synthase and has been implicated as an important contributor to endothelial dysfunction in ESRD patients 106. ADMA is not excreted in ESRD patients and its levels have been reported to be two to six times higher in this patient population as compared to non-uremic individuals ${ }^{107}$. In a recent clinical study in AVFs, patients with elevated ADMA levels at the time of percutaneous transluminal angioplasty of an initial AVF stenosis had a significantly increased risk of a recurrent AVF stenosis 108.

\subsubsection{Alternative origins of neointimal cells}

Although the traditional paradigm for the pathogenesis of neointimal hyperplasia has emphasized the migration of smooth muscle cells from the media to the intima, where they proliferate and contribute to the final volume of neointimal hyperplasia, a number of studies have reported that following coronary angioplasty or saphenous vein bypass grafting there is also a migration of cells (fibroblasts) from the adventitia, through the media, and into the intima, where these cells transform into "myofibroblasts" 109-111. In dialysis access, a number 
of recent studies in AVGs have supported the concept of a migration of adventitial cells into the intima where they contribute to final neointimal volume 59,112 . In addition, recent data from several experimental AVF stenosis models have shown that smooth muscle cells in the neointima, may in part, originate from bone-marrow-derived cells that bind to the site of vascular injury and later differentiate into a smooth muscle cell phenotype in the neointima $82,113,114$. From a therapeutic standpoint, it is likely that better information about the true source of neointimal cells will allow for the development of novel therapeutic interventions targeting specific cell types.

\subsection{Hemodynamic and vascular remodeling in hemodialysis access dysfunction}

A number of experimental studies have shown that turbulent, low flow, low fluid sheer stress are involved in neointimal hyperplasia development ${ }^{115-119}$. High sheer stress has been associated with vascular dilatation through inhibition of smooth muscle cell proliferation and high levels of nitric oxide release, whereas low sheer stress has been associated with smooth muscle cell proliferation and lack of vasodilatation 120-123. Poor hemodynamic profiles could be a risk factor for neointimal hyperplasia development and poor venous dilatation, and the degree of luminal stenosis is dependent upon both the magnitude of neointimal hyperplasia and the capacity for vasodilatation or vasocontriction. Therefore, a significant amount of neointimal hyperplasia and medial hypertrophy may not result in luminal stenosis in the presence of adequate vasodilatation, while a small amount of neointimal hyperplasia, but with poor vasodilatation, may result in severe venous stenosis 4,124. Unfortunately, the factors that are responsible for vascular remodeling are unknown, but adventitial angiogenesis and scar formation are hypothesized to play a significant role 125,126 . Thus, the ideal therapy for vascular stenosis would be an intervention that would prevent vascular constriction (adverse remodeling) and neointimal hyperplasia 4

\section{Central venous dialysis catheters}

CVC dysfunction and related-infection remains a common cause of morbidity, mortality, and high economic costs in treating chronic hemodialysis patients. This section will provide a brief overview of catheter dysfunction and catheter-related infections.

\subsection{Catheter dysfunction}

Catheter dysfunction can occur immediately after placement or in a catheter which has been previously functioning without difficulties, and most commonly manifests with low catheter blood flows during dialysis or negative arterial pressures on the dialysis machine ${ }^{6}$. In more severe cases catheter thrombosis is characterized by the inability to aspirate blood from the dialysis port ${ }^{6}$. Catheter dysfunction which occurs immediately after placement is most likely due to placement problems ${ }^{6}$.

Installation of a thrombolytic agent for 30 to 60 minutes is a treatment for catheter dysfunction, followed by a second installation if necessary ${ }^{6}$. Recently published studies have reported varied success rate when treating catheter dysfunction with thrombolytics, ranging anywhere between $60-95 \% 26,28,35,127,128$. When thrombolytic therapy is unsuccessful in providing adequate blood flow and adequate dialysis, despite repeated installations, then catheter exchange needs to be performed. The current K/DOQI guidelines recommends treatment with thrombolytic agents in all catheters with a persistently low blood flow rate $(<300 \mathrm{ml} / \mathrm{min})^{19}$. 
The current standard of care to prevent catheter thrombosis is installation of an anticoagulant in both dialysis ports at the completion of each dialysis session. In the United States, heparin is most commonly used, while in Europe citrate is the more common anticoagulant ${ }^{6}$. The studies to-date have shown similar efficacy when comparing citrate to heparin for prophylaxis of catheter thrombosis, but with fewer complications of systemic bleeding with citrate 129-132. A recent multicenter, randomized-controlled trial has reported that use of a thrombolytic, tissue plasminogen activator as a locking solution compared to heparin had reduced incidence of catheter dysfunction ${ }^{34}$.

\subsection{Catheter-related bacteremia}

Currently, a precise definition for diagnosis catheter-related bacteremia is lacking. More rigorous definitions require a positive blood culture obtained from the catheter and a peripheral vein with the quantitative colony count being at minimum four-fold higher from the catheter sample ${ }^{133}$. However, recently, the Infectious Disease Society of America has recognized the challenges in obtaining peripheral blood cultures from hemodialysis patients (e.g. priority for preserving veins and difficult cannulations) and has considered a definition of "possible" catheter-related bacteremia as positive blood culture obtained from the catheter in a symptomatic patient 134 .

The two main pathways where organisms can gain entry into the blood stream to initiate catheter-related bacteremia are intraluminal and extraluminal ${ }^{135}$. Organisms gain entrance through the bloodstream extraluminally through contact between the skin surface organisms and the external surface of the catheter at the time of catheter placement or following catheter placement before healing of the exit site or endothelialization of the subcutaneous tunnel 7 . Subsequently, the organisms colonize or migrate through the intracutaneous exterior tract of the catheter to the tip, allowing for hematagenous dispersion of the organisms and leading to catheter-related bacteremia 7. Intraluminal-derived infections results from the transfer of organisms from hand contact with the catheter, leading to contamination of the internal catheter surfaces ${ }^{7}$. Infection from the extraluminal pathway most commonly occurs immediately after catheter insertion, while infections from the intraluminal pathway occurs throughout the life of the catheter ${ }^{7}$. Irrespective of the route of bacterial entry, the bacteria will either adhere to the CVC or become incorporated into a fibrin sheath. Adherence of the bacterial organisms to the CVC initiates a common pathway of biofilm production. A mature biofilm is a self-sustaining colony of microorganism, guarded by an exopolysaccharide matrix, that is stimulated and secreted by the organism and very difficult to eradicate 7,136-140.

Catheter-related bacteremia can result in devastating complications such as endocarditis, osteomyelitis, thrombophlebitis, septic arthritis, spinal epidural abscess, and large atrial thrombi 30,31,141-149. The majority of isolated organisms from catheter-related bacteremia are gram-positive organisms (52-84\%) with Staph Aureus responsible for the majority of these organisms 7,30,31,143,150,151. Gram-negative are isolated in $27-36 \%$ of episodes and fungal isolated are relatively uncommon $(<10 \%)$ 141-143,149,152. Therefore, it is important to identify catheter-related bacteremia early so treatment can be initiated immediately.

\subsubsection{Treatment of catheter-related bacteremia}

Initial empiric antibiotic treatment should include broad-spectrum coverage for grampositive and gram-negative organisms using knowledge of the common organisms and 
sensitivity patterns that are grown at the dialysis center. Due to the high prevalence of methicillin-resistant Staph Aureus (MRSA), empiric therapy should include coverage for MRSA. When the specific organism and antibiotic sensitivities are identified, it is important to narrow the antibiotic therapy to prevent the development of drug resistant organisms. While the exact duration of antibiotic treatment for catheter-related bacteremia is uncertain, the Infectious Disease society of America recommends a 2 week course of antibiotics 153, while the K/DOQI guidelines recommends a 3 week course of antibiotics ${ }^{19}$. Other therapies, which have been used in conjunction with systemic antibiotics, to treat catheterrelated bacteremia are antibiotic catheter locks. A number of studies have shown that antibiotic locks (which may treat the biofilm layer) used in conjunction with systemic antibiotics, in tunneled dialysis catheters, have documented a 70\% cure rate 30,145,154-156.

Recent studies have evaluated pharmacologic therapies to prevent catheter-related bacteremia. Routine application of topical antibiotic ointments at the CVC exit such as mupirocin, povidine-iodine, and polysporin triple ointment has been associated with a 7393\% reduction in the risk of catheter-related bacteremia 7,151,157-159. Prophylactic antibiotic catheter locks have also recently been evaluated. A marked reduction in catheter-related bacteremia has been reported, ranging from 51-99\%, with use of a prophylactic antibiotic catheter locking solution 7,160-164. However, of concern, a recent study has shown emergence of gentamicin-resistant organisms after 6 months when using a gentamicin-heparin prophylactic catheter lock 165 .

The above strategies for treatment of catheter-related bacteremia apply to patients who are clinically stable. However, catheter removal, in addition to antibiotic therapy, should be the treatment of choice when patients: (1) are clinically unstable, (2) have persistent fever for 48 hours, (3) have evidence of tunnel infection, or (4) develop metastatic infectious complications ${ }^{7}$.

\section{Translating science to therapies in hemodialysis vascular access dysfunction: from the bench to bedside}

There are currently few if any effective therapies to treat hemodialysis vascular access stenosis and neointimal hyperplasia. However, the knowledge obtained in recent years regarding the pathology and pathogenesis of vascular access access dysfunction has provided a framework for development of therapies that target neointimal hyperplasia and vascular stenosis. The purpose of the next section is to (1) describe current therapies for AVF and AVG stenosis and (2) novel therapies using localized delivery systems for AVF and AVG.

\subsection{Systemic therapies}

Systemic therapies, such as dipyridamole, angiotensin-converting enzyme inhibitors, aspirin, and fish oil, from small clinical trials and observational studies have been shown to have the potential to block smooth muscle cell proliferation and migration and to prevent thrombosis in AVFs and AVGs ${ }^{166-170}$. Most recently, two large randomized controlled trials, sponsored by the National Institutes of Health, evaluating anti-platelet agents in AVG and AVF to prevent neointimal hyperplasia were published 16,171. In the AVG study, dipyridamole and aspirin, modestly reduced the risk of stenosis and improved primary unassisted patency ${ }^{171}$. In the AVF study clopidogrel reduced frequency of early thrombosis but did not improve AVF suitability defined as cannulation with two needles, minimum 
dialysis blood flow of $300 \mathrm{ml} / \mathrm{min}$, successful use $8 / 12$ dialysis sessions, and use after 120 days from creation 16 . While these two studies have shown some promising results, the clinical significance of these drugs used as standard treatment for hemodialysis access stenosis remains questionable.

Fish oil has been shown to prevent AVG stenosis and thrombosis in one randomized, controlled trial 172. Currently, another study evaluating fish oil and AVG stenosis and thrombosis is ongoing ${ }^{173}$. Other systemic agents, though not tested in randomized clinical trials, which have shown potential anti-proliferative effects targeting neointimal hyperplasia in CVD or PVD models, include peroxisome proliferation-activated receptor $\gamma$ agonist $174-176$, sirolimus 177, and imatinib mesylate 176,178,179.

\subsection{Radiation therapy}

Radiation therapy has been hypothesized to be a potential therapy to treat vascular stenosis due to its antiproliferative effects and potential beneficial effects of vascular remodeling 180 183. In experimental models, both external beam and endovascular radiation therapy has proven effective to reduce neointimal hyperplasia in AVF and AVG 184,185. However, in clinical studies, a recent randomized-controlled trial of in AVGs 25 patients showed that $42 \%$ of the radiated AVGs achieved the target lesion primary patency end point at 6 months as compared to $0 \%$ of the control group $(\mathrm{p}=0.015)$, but this did not translate into an improvement in secondary patency at either 6 or 12 months 186 .

\subsection{Far infrared therapy}

Infrared radiation is an invisible electromagnetic wave with a longer wavelength than that of visible light. In experimental models, far infrared therapy has been shown to improve skin blood flow and endothelial function in cardiovascular disease 187-189. The rationale for far infrared therapy to treat dialysis vascular access stenosis is that the dialysis vascular access in patients are located at a superficial site and improving access flow may improve vascular access performance. In the lone clinical study of far infrared in dialysis access in AVFs, patients who received far infrared therapy had improved access flows and longer unassisted patencies ${ }^{190}$.

\subsection{Local drug delivery systems for hemodialysis access}

The rationale behind local delivery of drugs treat hemodialysis vascular access stenosis is that (1) AVFs and AVGs could be the ideal clinical model for the use of perivascular therapies since these can be easily applied at the time of surgery, (2) perivascular therapies preferentially target the "active" adventitia, (3) studies have demonstrated that lipophilic molecules when placed over the adventitia rapidly diffuse through all the layers of the vessel wall, and (4) small amounts of otherwise toxic drugs can be safely delivered to the site of stenosis using the perivascular approach resulting in high local concentrations with minimal systemic toxicity ${ }^{4}$. The subsequent section will discuss local therapies to treat hemodialysis vascular access stenosis from experimental models and clinical studies.

\subsubsection{Drug eluting paclitaxel perivascular wraps}

Experimental studies have previously demonstrated the efficacy of paclitaxel eluting wraps in AVG stenosis likely due to anti-proliferative effects 191-193. In 2007, a large multi-center randomized-controlled study, evaluating the use of paclitaxel-eluting mesh wraps, Vascular 
Wrap ${ }^{\mathrm{TM}}$, (Angiotech Pharmaceuticals, Inc.; Vancouver, British Columbia, Canada), was initiated to study the effectiveness and safety of this therapy on primary AVG patency compared to a standard AVG. However, this study was recently suspended in 2009 following a data safety monitoring review, due to an imbalance in the incidence of infections in one of the arms (either control or treatment). An alternative approach is the use of sirolimus eluting COLL-R ${ }^{\circledR}$ wraps (Covalon Technologies Ltd: Mississauga, Ontario, Canada). An initial Phase II study demonstrated primary unassisted AVG patency of $75 \%$ and $38 \%$ at 1 and 2 years respectively with these wraps 194 .

\subsubsection{Endothelial cell loaded gel foam wraps}

The rationale behind the use of these wraps is that the endothelial cell (in addition to lining blood vessels) is also a "bioreactor" which produces a large number of beneficial mediators that reduces thrombosis, inflammation, stenosis, and increases lumen diameter. Initial experimental studies have documented a beneficial effect of endothelial cell loaded gel-foam wraps in porcine models of AV fistula and graft stenosis ${ }^{195-198}$. A recent Phase II study ("V-

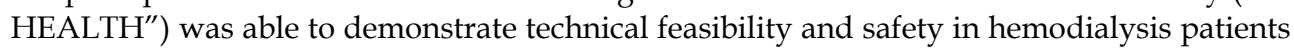
who received a "Vascugel ${ }^{\circledR}$ " wrap loaded with treated human aortic endothelial cells at the time of AVF or AVG placement ${ }^{97}$. A phase III multi-center randomized-controlled study using the Vascugel ${ }^{\circledR}$ (Pervasis Therapeutics, Inc., Cambridge, MA) wraps in human AVGs is currently being designed.

\subsubsection{Vascular Endothelial Growth Factor D (VEGF-D) gene therapy}

In animal models of angioplasty induced restenosis, the delivery of adenoviral particles encoding for vascular-endothelial growth factor $C$ to the site of vascular injury has been shown to trigger the release of nitric oxide and prostacyclin and reduce neointimal hyperplasia ${ }^{199}$. Preliminary studies on the use of VEGF-D gene therapy (using a packaged adenoviral vector and a biodegradable local delivery device (collar) made of collagen wrapped at the venous anastomosis at the time of surgery), "Trinam ${ }^{\circledR ”}$ (Ark Therapeutics; London, UK), in patients receiving AVGs, have been able to document technical feasibility and safety. A phase III study using this technology was initiated in 2009 but terminated in 2010 due to poor enrollment.

\subsubsection{Recombinant elastase PRT-201}

PRT-201 (Proteon Therapeutics; Waltham, MA) is a recombinant pancreatic elastase topically applied at the outflow vein at the time of surgery access creation which has been shown to result in both arterial and venous dilation and an increase in AVF blood flow in experimental models 200 . The clinical benefit of this approach is the potential ability to enhance AVF maturation (through rapid vascular dilation) and prevent venous stenosis in AVGs. A phase II study using this novel technology is ongoing in the United States evaluating this therapy and whether or not it improves primary patency and cumulative survival in AVG and AVF, as well as safety.

\subsection{Endovascular stent therapy}

Endovascular vascular therapies (angioplasty or angioplasty with stent placement) remains the only true intervention available to treat vascular stenosis. The main advantage of stent therapy after angioplasty is a reduction in adverse remodeling. In dialysis access, placement 
of bare metal stents after angioplasty compared to angioplasty 201 alone has been shown to improve primary patency 202,203 . However, bare-metal stents have yielded poor results due to aggressive development of in-stent restenosis. In experimental models of dialysis access in AVGs, drug-eluting stents have shown to reduce neointimal hyperplasia and improve luminal stenosis compared to bare-metal stents ${ }^{204}$. However, there are no clinical studies evaluating drug-eluting stents in dialysis access to date.

Stent grafts (covered stents constructed from the same material of AVGs) have received recent attention as a therapy for prevention of restenosis due to its ability to prevent elastic recoil and inability of the neointimal cells to penetrate the covered barrier. A recently published multicenter, randomized controlled, clinical trial showed stent grafts (Bard Peripheral Vascular, Tempe, AZ), placed after angioplasty, to treat venous stenosis had better primary unassisted patency compared to angioplasty alone ${ }^{205}$. This is the only treatment to date that has shown to be effective to treat vascular access stenosis in a large, randomized, clinical trial.

\subsection{Improving hemodynamics}

Hemodynamic sheer stresses play a significant role in development of neointimal hyperplasia $87,112,206,207$. Therefore, altering the sheer stress pattern to prevent turbulent, lowflow, and low-sheer stresses could reduce the development of neointimal hyperplasia. Previous clinical data to date to support such an intervention comes from several studies evaluating cuffed AVG grafts ("Venaflo"; Bard Vascular, Tempe Arizona) ${ }^{208-210}$. In a recent randomized control trial evaluating cuffed vs non-cuffed AVG, cuffed AVGs showed better primary patency and cumulative survival 211. Finally, results from a newly developed anastomotic implant device, "OptiflowTM" (Bioconnect Systems; Ambler, PA), to connect the artery and vein in AVFs and improve hemodynamics by providing a symmetric flow pattern, have shown a primary patency of $83 \%$ at 90 days ${ }^{212}$. This primary patency rate was higher compared to other similarly published studies ${ }^{213}$.

\section{Future perspectives: new frontiers in research}

In the last decade our knowledge of vascular access dysfunction has significantly evolved. We now understand that the most common pathologic lesion seen in AVF and AVG dysfunction is aggressive venous neointimal hyperplasia, and biofilms and fibrin sheaths play a major role in CVC infection and dysfunction. In order to advance the field further, we need to further our current understanding of both the clinical and experimental pathways that result in venous neointimal hyperplasia and mechanisms that lead to biofilm and fibrin sheath production in CVCs by using the advanced technologies and tools in cellular and molecular biology, bioengineering, genomics, proteomics, and vascular imaging (ultrasound, computed tomography, and magnetic resonance imaging) 65,124,214. Finally, small and large animal models of AVF and AVG, which a number of investigators in this field have already developed $61,93,207,215-217$, will play an essential role in "translating" our knowledge of pathophysiologic mechanisms in vascular access dysfunction to novel therapies for patients.

\section{Conclusion}

The magnitude and costs of dialysis access dysfunction is clearly evident, and will only become magnified in the coming years as the prevalent dialysis population continues to 
increase. Only by launching a "translational" research initiative ("from animal to human") can recent advances in the understanding of the mechanisms of neointimal hyperplasia formation and vascular stenosis and catheter dysfunction be translated to the development of novel effective therapies for patients.

\section{References}

[1] Collins AJ, Foley RN, Gilbertson DT, Chen SC. The state of chronic kidney disease, ESRD, and morbidity and mortality in the first year of dialysis. Clin J Am Soc Nephrol 2009;4 Suppl 1:S5-11.

[2] Feldman HI, Kobrin S, Wasserstein A. Hemodialysis vascular access morbidity. J Am Soc Nephrol 1996;7:523-35.

[3] Dhingra RK, Young EW, Hulbert-Shearon TE, Leavey SF, Port FK. Type of vascular access and mortality in U.S. hemodialysis patients. Kidney Int 2001;60:1443-51.

[4] Roy-Chaudhury P, Sukhatme VP, Cheung AK. Hemodialysis vascular access dysfunction: a cellular and molecular viewpoint. J Am Soc Nephrol 2006;17:111227.

[5] Roy-Chaudhury P, Kelly BS, Melhem M, et al. Vascular access in hemodialysis: issues, management, and emerging concepts. Cardiol Clin 2005;23:249-73.

[6] Allon M. Current management of vascular access. Clin J Am Soc Nephrol 2007;2:786-800.

[7] Lok CE, Mokrzycki MH. Prevention and management of catheter-related infection in hemodialysis patients. Kidney Int 2011;79:587-98.

[8] Moist LM, Trpeski L, Na Y, Lok CE. Increased hemodialysis catheter use in Canada and associated mortality risk: data from the Canadian Organ Replacement Registry 2001-2004. Clin J Am Soc Nephrol 2008;3:1726-32.

[9] Oliver MJ, McCann RL, Indridason OS, Butterly DW, Schwab SJ. Comparison of transposed brachiobasilic fistulas to upper arm grafts and brachiocephalic fistulas. Kidney Int 2001;60:1532-9.

[10] Palder SB, Kirkman RL, Whittemore AD, Hakim RM, Lazarus JM, Tilney NL. Vascular access for hemodialysis. Patency rates and results of revision. Annals of surgery 1985;202:235-9.

[11] Allon M. Current management of vascular access. Clinical journal of the American Society of Nephrology : CJASN 2007;2:786-800.

[12] Allon M, Robbin ML. Increasing arteriovenous fistulas in hemodialysis patients: problems and solutions. Kidney Int 2002;62:1109-24.

[13] Schwab SJ, Harrington JT, Singh A, et al. Vascular access for hemodialysis. Kidney international 1999;55:2078-90.

[14] Lok CE, Allon M, Moist L, Oliver MJ, Shah H, Zimmerman D. Risk equation determining unsuccessful cannulation events and failure to maturation in arteriovenous fistulas (REDUCE FTM I). J Am Soc Nephrol 2006;17:3204-12.

[15] Lee T, Barker J, Allon M. Comparison of survival of upper arm arteriovenous fistulas and grafts after failed forearm fistula. J Am Soc Nephrol 2007;18:1936-41.

[16] Dember LM, Beck GJ, Allon M, et al. Effect of Clopidogrel on Early Failure of Arteriovenous Fistulas for Hemodialysis: A Randomized Controlled Trial. JAMA 2008;299:2164-71.

[17] Raju S. PTFE grafts for hemodialysis access. Techniques for insertion and management of complications. Annals of surgery 1987;206:666-73. 
[18] Fan PY, Schwab SJ. Vascular access: concepts for the 1990s. Journal of the American Society of Nephrology : JASN 1992;3:1-11.

[19] Clinical Practice Guidelines for Vascular Access. Am J Kidney Dis 2006;48:S176-S273.

[20] Ethier J, Mendelssohn DC, Elder SJ, et al. Vascular access use and outcomes: an international perspective from the Dialysis Outcomes and Practice Patterns Study. Nephrol Dial Transplant 2008;23:3219-26.

[21] Maya ID, Weatherspoon J, Young CJ, Barker J, Allon M. Increased risk of infection associated with polyurethane dialysis grafts. Semin Dial 2007;20:616-20.

[22] Schwab SJ. Reducing the risk of hemodialysis access. American journal of kidney diseases : the official journal of the National Kidney Foundation 1999;34:362-3.

[23] Akoh JA, Patel N. Infection of hemodialysis arteriovenous grafts. The journal of vascular access 2010;11:155-8.

[24] Schwab SJ, Oliver MJ, Suhocki P, McCann R. Hemodialysis arteriovenous access: detection of stenosis and response to treatment by vascular access blood flow. Kidney Int 2001;59:358-62.

[25] Fan PY. Acute vascular access: new advances. Advances in renal replacement therapy 1994;1:90-8.

[26] Schwab SJ, Buller GL, McCann RL, Bollinger RR, Stickel DL. Prospective evaluation of a Dacron cuffed hemodialysis catheter for prolonged use. American journal of kidney diseases : the official journal of the National Kidney Foundation 1988;11:166-9.

[27] Moss AH, McLaughlin MM, Lempert KD, Holley JL. Use of a silicone catheter with a Dacron cuff for dialysis short-term vascular access. American journal of kidney diseases : the official journal of the National Kidney Foundation 1988;12:492-8.

[28] Moss AH, Vasilakis C, Holley JL, Foulks CJ, Pillai K, McDowell DE. Use of a silicone dual-lumen catheter with a Dacron cuff as a long-term vascular access for hemodialysis patients. American journal of kidney diseases : the official journal of the National Kidney Foundation 1990;16:211-5.

[29] Allon M. Dialysis catheter-related bacteremia: treatment and prophylaxis. Am J Kidney Dis 2004;44:779-91.

[30] Krishnasami Z, Carlton D, Bimbo L, et al. Management of hemodialysis catheterrelated bacteremia with an adjunctive antibiotic lock solution. Kidney Int 2002;61:1136-42.

[31] Tanriover B, Carlton D, Saddekni S, et al. Bacteremia associated with tunneled dialysis catheters: comparison of two treatment strategies. Kidney Int 2000;57:2151-5.

[32] Lee T, Barker J, Allon M. Tunneled catheters in hemodialysis patients: reasons and subsequent outcomes. Am J Kidney Dis 2005;46:501-8.

[33] Allon M. Treatment guidelines for dialysis catheter-related bacteremia: an update. Am J Kidney Dis 2009;54:13-7.

[34] Hemmelgarn BR, Moist LM, Lok CE, et al. Prevention of dialysis catheter malfunction with recombinant tissue plasminogen activator. N Engl J Med 2011;364:303-12.

[35] Suhocki PV, Conlon PJ, Jr., Knelson MH, Harland R, Schwab SJ. Silastic cuffed catheters for hemodialysis vascular access: thrombolytic and mechanical correction of malfunction. American journal of kidney diseases : the official journal of the National Kidney Foundation 1996;28:379-86.

[36] Crain MR, Mewissen MW, Ostrowski GJ, Paz-Fumagalli R, Beres RA, Wertz RA. Fibrin sleeve stripping for salvage of failing hemodialysis catheters: technique and initial results. Radiology 1996;198:41-4. 
[37] Caruana RJ, Raja RM, Zeit RM, Goldstein SJ, Kramer MS. Thrombotic complications of indwelling central catheters used for chronic hemodialysis. American journal of kidney diseases : the official journal of the National Kidney Foundation 1987;9:497501.

[38] Maya ID, Saddekni S, Allon M. Treatment of refractory central vein stenosis in hemodialysis patients with stents. Semin Dial 2007;20:78-82.

[39] Schwab SJ, Quarles LD, Middleton JP, Cohan RH, Saeed M, Dennis VW. Hemodialysisassociated subclavian vein stenosis. Kidney international 1988;33:1156-9.

[40] Tokars JI, Miller ER, Alter MJ, Arduino MJ. National surveillance of dialysis-associated diseases in the United States, 1997. Semin Dial 2000;13:75-85.

[41] NKF-DOQI clinical practice guidelines for vascular access. National Kidney Foundation-Dialysis Outcomes Quality Initiative. Am J Kidney Dis 1997;30:S150-91.

[42] Fistula First National Access Improvements Initiative. Available at: http://www.fistulafirst.org/. Accessed January 23, 2011.

[43] Gold JA, Hoffman K. Fistula First: the National Vascular Access Improvement Initiative. Wmj 2006;105:71-3.

[44] Lok CE. Fistula first initiative: advantages and pitfalls. Clin J Am Soc Nephrol 2007;2:1043-53.

[45] Peters VJ, Clemons G, Augustine B. "Fistula First" as a CMS breakthrough initiative: improving vascular access through collaboration. Nephrol Nurs J 2005;32:686-7.

[46] National Kidney Foundation: DOQI Clinical Practice Guidelines for Vascular Access: Update 2000. Am J Kidney Dis 2001;37:S137-S81.

[47] U.S. Renal Data System, USRDS 2009 Annual Data Report: Atlas of CKD and ESRD in the United States, National Institutes of Health, National Institute of Diabetes and Digestive and Kidney Diseases, Bethesda, MD, 2009.

[48] Kinney R. 2005 Annual Report: ESRD Clinical Performance Measures Project. American Journal of Kidney Diseases 2006;48:S1-S105.

[49] Xue JL, Dahl D, Ebben JP, Collins AJ. The association of initial hemodialysis access type with mortality outcomes in elderly Medicare ESRD patients. Am J Kidney Dis 2003;42:1013-9.

[50] Oliver MJ, Rothwell DM, Fung K, Hux JE, Lok CE. Late creation of vascular access for hemodialysis and increased risk of sepsis. J Am Soc Nephrol 2004;15:1936-42.

[51] Allon M, Daugirdas J, Depner TA, Greene T, Ornt D, Schwab SJ. Effect of change in vascular access on patient mortality in hemodialysis patients. Am J Kidney Dis 2006;47:469-77.

[52] Lacson E, Jr., Wang W, Hakim RM, Teng M, Lazarus JM. Associates of mortality and hospitalization in hemodialysis: potentially actionable laboratory variables and vascular access. Am J Kidney Dis 2009;53:79-90.

[53] Foley RN, Chen SC, Collins AJ. Hemodialysis access at initiation in the United States, 2005 to 2007: still "catheter first". Hemodial Int 2009;13:533-42.

[54] Astor BC, Eustace JA, Powe NR, Klag MJ, Fink NE, Coresh J. Type of vascular access and survival among incident hemodialysis patients: the Choices for Healthy Outcomes in Caring for ESRD (CHOICE) Study. J Am Soc Nephrol 2005;16:1449-55.

[55] Bradbury BD, Fissell RB, Albert JM, et al. Predictors of early mortality among incident US hemodialysis patients in the Dialysis Outcomes and Practice Patterns Study (DOPPS). Clin J Am Soc Nephrol 2007;2:89-99.

[56] Allon M. Prophylaxis against dialysis catheter-related bacteremia: a glimmer of hope. Am J Kidney Dis 2008;51:165-8. 
[57] Rayner HC, Pisoni RL, Gillespie BW, et al. Creation, cannulation and survival of arteriovenous fistulae: data from the Dialysis Outcomes and Practice Patterns Study. Kidney Int 2003;63:323-30.

[58] Reed SD, Friedman JY, Engemann JJ, et al. Costs and outcomes among hemodialysisdependent patients with methicillin-resistant or methicillin-susceptible Staphylococcus aureus bacteremia. Infection control and hospital epidemiology : the official journal of the Society of Hospital Epidemiologists of America 2005;26:175-83.

[59] Roy-Chaudhury P, McKee, L., Miller, M., Reaves, A., Armstrong, J., Duncan, H., Munda, R., Kelly, B., Heffelfinger, S. Adventitial fibroblasts contribute to venous neointimal hyperplasia in PTFE grafts [Abstract]. J Am Soc Nephrol 2001;12:301A.

[60] Weiss MF, Scivittaro V, Anderson JM. Oxidative stress and increased expression of growth factors in lesions of failed hemodialysis access. Am J Kidney Dis 2001;37:970-80.

[61] Kelly BS, Heffelfinger SC, Whiting JF, et al. Aggressive venous neointimal hyperplasia in a pig model of arteriovenous graft stenosis. Kidney Int 2002;62:2272-80.

[62] Roy-Chaudhury P, Kelly BS, Miller MA, et al. Venous neointimal hyperplasia in polytetrafluoroethylene dialysis grafts. Kidney Int 2001;59:2325-34.

[63] Wang Y, Krishnamoorthy M, Banerjee R, et al. Venous stenosis in a pig arteriovenous fistula model--anatomy, mechanisms and cellular phenotypes. Nephrol Dial Transplant 2008;23:525-33.

[64] Roy-Chaudhury P, Wang Y, Krishnamoorthy M, et al. Cellular phenotypes in human stenotic lesions from haemodialysis vascular access. Nephrol Dial Transplant 2009;24:2786-91.

[65] Lee T, Roy-Chaudhury P. Advances and new frontiers in the pathophysiology of venous neointimal hyperplasia and dialysis access stenosis. Adv Chronic Kidney Dis 2009;16:329-38.

[66] Roy-Chaudhury P, Arend L, Zhang J, et al. Neointimal hyperplasia in early arteriovenous fistula failure. Am J Kidney Dis 2007;50:782-90.

[67] Ene-Iordache B, Mosconi L, Antiga L, et al. Radial artery remodeling in response to shear stress increase within arteriovenous fistula for hemodialysis access. Endothelium 2003;10:95-102.

[68] Paszkowiak JJ, Dardik A. Arterial wall shear stress: observations from the bench to the bedside. Vascular and endovascular surgery 2003;37:47-57.

[69] Huynh TN, Chacko BK, Teng X, et al. Effects of venous needle turbulence during ex vivo hemodialysis on endothelial morphology and nitric oxide formation. Journal of biomechanics 2007;40:2158-66.

[70] Chang CJ, Ko PJ, Hsu LA, et al. Highly increased cell proliferation activity in the restenotic hemodialysis vascular access after percutaneous transluminal angioplasty: implication in prevention of restenosis. Am J Kidney Dis 2004;43:74-84.

[71] Lin T, Horsfield C, Robson MG. Arteriovenous fistula in the rat tail: a new model of hemodialysis access dysfunction. Kidney Int 2008;74:528-31.

[72] Roy-Chaudhury P, Melhem M, Husted T, Kelly BS. Solutions for hemodialysis vascular access dysfunction: thinking out of the box!! J Vasc Access 2005;6:3-8.

[73] Lin CC, Yang WC, Lin SJ, et al. Length polymorphism in heme oxygenase-1 is associated with arteriovenous fistula patency in hemodialysis patients. Kidney Int 2006;69:165-72. 
[74] Heine GH, Ulrich C, Kohler H, Girndt M. Is AV fistula patency associated with angiotensin-converting enzyme (ACE) polymorphism and ACE inhibitor intake? Am J Nephrol 2004;24:461-8.

[75] Heine GH, Ulrich C, Sester U, Sester M, Kohler H, Girndt M. Transforming growth factor beta1 genotype polymorphisms determine AV fistula patency in hemodialysis patients. Kidney Int 2003;64:1101-7.

[76] Girndt M, Heine GH, Ulrich C, Kohler H. Gene polymorphism association studies in dialysis: vascular access. Semin Dial 2007;20:63-7.

[77] Lee $T$, Chauhan V, Krishnamoorthy M, et al. Severe venous neointimal hyperplasia prior to dialysis access surgery. Nephrology, dialysis, transplantation : official publication of the European Dialysis and Transplant Association - European Renal Association 2011.

[78] Wali MA, Eid RA, Al-Homrany MA. Smooth muscle changes in the cephalic vein of renal failure patients before use as an arteriovenous fistula (AVF). J Smooth Muscle Res 2002;38:75-85.

[79] Wali MA, Eid RA, Dewan M, Al-Homrany MA. Intimal changes in the cephalic vein of renal failure patients before arterio-venous fistula (AVF) construction. J Smooth Muscle Res 2003;39:95-105.

[80] Wali MA, Eid RA, Dewan M, Al-Homrany MA. Pre-existing histopathological changes in the cephalic vein of renal failure patients before arterio-venous fistula (AVF) construction. Ann Thorac Cardiovasc Surg 2006;12:341-8.

[81] Feinfeld DA, Batista R, Mir R, Babich D. Changes in venous histology in chronic hemodialysis patients. Am J Kidney Dis 1999;34:702-5.

[82] Castier Y, Lehoux S, Hu Y, Foteinos G, Tedgui A, Xu Q. Characterization of neointima lesions associated with arteriovenous fistulas in a mouse model. Kidney Int 2006;70:315-20.

[83] Dixon BS. Why don't fistulas mature? Kidney Int 2006;70:1413-22.

[84] Rotmans JI, Velema E, Verhagen HJ, et al. Matrix metalloproteinase inhibition reduces intimal hyperplasia in a porcine arteriovenous-graft model. J Vasc Surg 2004;39:432-9.

[85] Tronc F, Mallat Z, Lehoux S, Wassef M, Esposito B, Tedgui A. Role of matrix metalloproteinases in blood flow-induced arterial enlargement: interaction with NO. Arterioscler Thromb Vasc Biol 2000;20:E120-6.

[86] Misra S, Doherty MG, Woodrum D, et al. Adventitial remodeling with increased matrix metalloproteinase- 2 activity in a porcine arteriovenous polytetrafluoroethylene grafts. Kidney Int 2005;68:2890-900.

[87] Misra S, Fu AA, Puggioni A, et al. Increased shear stress with upregulation of VEGF-A and its receptors and MMP-2, MMP-9, and TIMP-1 in venous stenosis of hemodialysis grafts. Am J Physiol Heart Circ Physiol 2008;294:H2219-30.

[88] Misra S, Fu AA, Rajan DK, et al. Expression of hypoxia inducible factor-1 alpha, macrophage migration inhibition factor, matrix metalloproteinase-2 and -9 , and their inhibitors in hemodialysis grafts and arteriovenous fistulas. J Vasc Interv Radiol 2008;19:252-9.

[89] Nath KA. Heme oxygenase-1: a provenance for cytoprotective pathways in the kidney and other tissues. Kidney Int 2006;70:432-43.

[90] Juncos JP, Tracz MJ, Croatt AJ, et al. Genetic deficiency of heme oxygenase- 1 impairs functionality and form of an arteriovenous fistula in the mouse. Kidney Int 2008;74:47-51. 
[91] Sezer S, Ozdemir FN, Arat Z, Turan M, Haberal M. Triad of malnutrition, inflammation, and atherosclerosis in hemodialysis patients. Nephron 2002;91:45662.

[92] Kokubo T, Ishikawa N, Uchida $\mathrm{H}$, et al. CKD accelerates development of neointimal hyperplasia in arteriovenous fistulas. J Am Soc Nephrol 2009;20:1236-45.

[93] Juncos JP, Grande JP, Kang L, et al. MCP-1 contributes to arteriovenous fistula failure. Journal of the American Society of Nephrology : JASN 2011;22:43-8.

[94] Stracke S, Konner K, Kostlin I, et al. Increased expression of TGF-beta1 and IGF-I in inflammatory stenotic lesions of hemodialysis fistulas. Kidney Int 2002;61:1011-9.

[95] Li L, Terry CM, Shiu Y-TE, Cheung AK. Neointimal hyperplasia associated with synthetic hemodialysis grafts. Kidney Int 2008;74:1247-61.

[96] Mattana J, Effiong C, Kapasi A, Singhal PC. Leukocyte-polytetrafluoroethylene interaction enhances proliferation of vascular smooth muscle cells via tumor necrosis factor-alpha secretion. Kidney Int 1997;52:1478-85.

[97] Conte MS, Nugent HM, Gaccione P, Guleria I, Roy-Chaudhury P, Lawson JH. Multicenter phase I/II trial of the safety of allogeneic endothelial cell implants after the creation of arteriovenous access for hemodialysis use: the V-HEALTH study. J Vasc Surg 2009;50:1359-68 e1.

[98] Shuhaiber JH, Evans AN, Massad MG, Geha AS. Mechanisms and future directions for prevention of vein graft failure in coronary bypass surgery. European journal of cardio-thoracic surgery : official journal of the European Association for Cardiothoracic Surgery 2002;22:387-96.

[99] Langille BL, O'Donnell F. Reductions in arterial diameter produced by chronic decreases in blood flow are endothelium-dependent. Science 1986;231:405-7.

[100] Ignarro LJ, Buga GM, Wood KS, Byrns RE, Chaudhuri G. Endothelium-derived relaxing factor produced and released from artery and vein is nitric oxide. Proceedings of the National Academy of Sciences of the United States of America 1987;84:9265-9.

[101] Bolton CH, Downs LG, Victory JG, et al. Endothelial dysfunction in chronic renal failure: roles of lipoprotein oxidation and pro-inflammatory cytokines. Nephrol Dial Transplant 2001;16:1189-97.

[102] Ghiadoni L, Cupisti A, Huang Y, et al. Endothelial dysfunction and oxidative stress in chronic renal failure. J Nephrol 2004;17:512-9.

[103] Kim YO, Choi YJ, Kim JI, et al. The impact of intima-media thickness of radial artery on early failure of radiocephalic arteriovenous fistula in hemodialysis patients. J Korean Med Sci 2006;21:284-9.

[104] Kim YO, Song HC, Yoon SA, et al. Preexisting intimal hyperplasia of radial artery is associated with early failure of radiocephalic arteriovenous fistula in hemodialysis patients. Am J Kidney Dis 2003;41:422-8.

[105] Ku YM, Kim YO, Kim JI, et al. Ultrasonographic measurement of intima-media thickness of radial artery in pre-dialysis uraemic patients: comparison with histological examination. Nephrol Dial Transplant 2006;21:715-20.

[106] Zoccali C. Endothelial damage, asymmetric dimethylarginine and cardiovascular risk in end-stage renal disease. Blood Purif 2002;20:469-72.

[107] Cooke JP. Does ADMA cause endothelial dysfunction? Arterioscler Thromb Vasc Biol 2000;20:2032-7.

[108] Wu CC, Wen SC, Yang CW, Pu SY, Tsai KC, Chen JW. Plasma ADMA predicts restenosis of arteriovenous fistula. J Am Soc Nephrol 2009;20:213-22. 
[109] Scott NA, Cipolla GD, Ross CE, et al. Identification of a potential role for the adventitia in vascular lesion formation after balloon overstretch injury of porcine coronary arteries. Circulation 1996;93:2178-87.

[110] Shi Y, O'Brien JE, Fard A, Mannion JD, Wang D, Zalewski A. Adventitial myofibroblasts contribute to neointimal formation in injured porcine coronary arteries. Circulation 1996;94:1655-64.

[111] Shi Y, O'Brien JE, Jr., Mannion JD, et al. Remodeling of autologous saphenous vein grafts. The role of perivascular myofibroblasts. Circulation 1997;95:2684-93.

[112] Li L, Terry CM, Blumenthal DK, et al. Cellular and morphological changes during neointimal hyperplasia development in a porcine arteriovenous graft model. Nephrol Dial Transplant 2007;22:3139-46.

[113] Caplice NM, Wang S, Tracz M, et al. Neoangiogenesis and the presence of progenitor cells in the venous limb of an arteriovenous fistula in the rat. Am J Physiol Renal Physiol 2007;293:F470-5.

[114] Diao Y, Guthrie S, Xia SL, et al. Long-term engraftment of bone marrow-derived cells in the intimal hyperplasia lesion of autologous vein grafts. Am J Pathol 2008;172:839-48.

[115] Haruguchi H, Teraoka S. Intimal hyperplasia and hemodynamic factors in arterial bypass and arteriovenous grafts: a review. Journal of artificial organs : the official journal of the Japanese Society for Artificial Organs 2003;6:227-35.

[116] Sivanesan S, How TV, Black RA, Bakran A. Flow patterns in the radiocephalic arteriovenous fistula: an in vitro study. Journal of biomechanics 1999;32:915-25.

[117] Krishnamoorthy MK, Banerjee RK, Wang Y, et al. Hemodynamic wall shear stress profiles influence the magnitude and pattern of stenosis in a pig AV fistula. Kidney Int 2008;74:1410-9.

[118] Paszkowiak JJ, Dardik A. Arterial wall shear stress: observations from the bench to the bedside. Vasc Endovascular Surg 2003;37:47-57.

[119] Corpataux JM, Haesler E, Silacci P, Ris HB, Hayoz D. Low-pressure environment and remodelling of the forearm vein in Brescia-Cimino haemodialysis access. Nephrol Dial Transplant 2002;17:1057-62.

[120] Mondy JS, Lindner V, Miyashiro JK, Berk BC, Dean RH, Geary RL. Platelet-derived growth factor ligand and receptor expression in response to altered blood flow in vivo. Circulation research 1997;81:320-7.

[121] Sterpetti AV, Cucina A, Santoro L, Cardillo B, Cavallaro A. Modulation of arterial smooth muscle cell growth by haemodynamic forces. Eur J Vasc Surg 1992;6:16-20.

[122] Kraiss LW, Geary RL, Mattsson EJ, Vergel S, Au YP, Clowes AW. Acute reductions in blood flow and shear stress induce platelet-derived growth factor-A expression in baboon prosthetic grafts. Circulation research 1996;79:45-53.

[123] Ueba H, Kawakami M, Yaginuma T. Shear stress as an inhibitor of vascular smooth muscle cell proliferation. Role of transforming growth factor-beta 1 and tissue-type plasminogen activator. Arteriosclerosis, thrombosis, and vascular biology 1997;17:1512-6.

[124] Roy-Chaudhury P, Lee TC. Vascular stenosis: biology and interventions. Curr Opin Nephrol Hypertens 2007;16:516-22.

[125] O'Brien JE, Jr., Shi Y, Fard A, Bauer T, Zalewski A, Mannion JD. Wound healing around and within saphenous vein bypass grafts. The Journal of thoracic and cardiovascular surgery 1997;114:38-45. 
[126] Kwon HM, Sangiorgi G, Ritman EL, et al. Enhanced coronary vasa vasorum neovascularization in experimental hypercholesterolemia. J Clin Invest 1998;101:1551-6.

[127] Daeihagh P, Jordan J, Chen J, Rocco M. Efficacy of tissue plasminogen activator administration on patency of hemodialysis access catheters. American journal of kidney diseases : the official journal of the National Kidney Foundation 2000;36:759.

[128] Lund GB, Trerotola SO, Scheel PF, Jr., et al. Outcome of tunneled hemodialysis catheters placed by radiologists. Radiology 1996;198:467-72.

[129] Grudzinski L, Quinan P, Kwok S, Pierratos A. Sodium citrate 4\% locking solution for central venous dialysis catheters--an effective, more cost-efficient alternative to heparin. Nephrology, dialysis, transplantation : official publication of the European Dialysis and Transplant Association - European Renal Association 2007;22:471-6.

[130] Lok CE, Appleton D, Bhola C, Khoo B, Richardson RM. Trisodium citrate 4\%--an alternative to heparin capping of haemodialysis catheters. Nephrology, dialysis, transplantation : official publication of the European Dialysis and Transplant Association - European Renal Association 2007;22:477-83.

[131] Dogra GK, Herson H, Hutchison B, et al. Prevention of tunneled hemodialysis catheter-related infections using catheter-restricted filling with gentamicin and citrate: a randomized controlled study. J Am Soc Nephrol 2002;13:2133-9.

[132] Weijmer MC, van den Dorpel MA, Van de Ven PJ, et al. Randomized, clinical trial comparison of trisodium citrate $30 \%$ and heparin as catheter-locking solution in hemodialysis patients. Journal of the American Society of Nephrology : JASN 2005;16:2769-77.

[133] Mermel LA, Farr BM, Sherertz RJ, et al. Guidelines for the management of intravascular catheter-related infections. Clinical infectious diseases : an official publication of the Infectious Diseases Society of America 2001;32:1249-72.

[134] Mermel LA, Allon M, Bouza E, et al. Clinical practice guidelines for the diagnosis and management of intravascular catheter-related infection: 2009 Update by the Infectious Diseases Society of America. Clinical infectious diseases : an official publication of the Infectious Diseases Society of America 2009;49:1-45.

[135] Cheesbrough JS, Finch RG, Burden RP. A prospective study of the mechanisms of infection associated with hemodialysis catheters. The Journal of infectious diseases 1986;154:579-89.

[136] Costerton JW. In response to: In vivo efficacy of silver-coated (Sil-zone) infectionresistant polyester fabric against a biofilm-producing bacteria, Staphylococcus epidermidis. J Heart Valve Disease; 1998;7:524-530. J Heart Valve Dis 1999;8:346-8.

[137] Costerton JW. Introduction to biofilm. Int J Antimicrob Agents 1999;11:217-21; discussion 37-9.

[138] Costerton JW, Stewart PS, Greenberg EP. Bacterial biofilms: a common cause of persistent infections. Science 1999;284:1318-22.

[139] Donlan RM, Costerton JW. Biofilms: survival mechanisms of clinically relevant microorganisms. Clin Microbiol Rev 2002;15:167-93.

[140] Hoyle BD, Alcantara J, Costerton JW. Pseudomonas aeruginosa biofilm as a diffusion barrier to piperacillin. Antimicrobial agents and chemotherapy 1992;36:2054-6.

[141] Mokrzycki MH, Zhang M, Cohen H, Golestaneh L, Laut JM, Rosenberg SO. Tunnelled haemodialysis catheter bacteraemia: risk factors for bacteraemia recurrence, infectious complications and mortality. Nephrology, dialysis, transplantation : 
official publication of the European Dialysis and Transplant Association - European Renal Association 2006;21:1024-31.

[142] Beathard GA. Management of bacteremia associated with tunneled-cuffed hemodialysis catheters. Journal of the American Society of Nephrology : JASN 1999;10:1045-9.

[143] Marr KA, Sexton DJ, Conlon PJ, Corey GR, Schwab SJ, Kirkland KB. Catheter-related bacteremia and outcome of attempted catheter salvage in patients undergoing hemodialysis. Annals of internal medicine 1997;127:275-80.

[144] Negulescu O, Coco M, Croll J, Mokrzycki MH. Large atrial thrombus formation associated with tunneled cuffed hemodialysis catheters. Clinical nephrology 2003;59:40-6.

[145] Poole CV, Carlton D, Bimbo L, Allon M. Treatment of catheter-related bacteraemia with an antibiotic lock protocol: effect of bacterial pathogen. Nephrol Dial Transplant 2004;19:1237-44.

[146] Kovalik EC, Raymond JR, Albers FJ, et al. A clustering of epidural abscesses in chronic hemodialysis patients: risks of salvaging access catheters in cases of infection. Journal of the American Society of Nephrology : JASN 1996;7:2264-7.

[147] Ghani MK, Boccalandro F, Denktas AE, Barasch E. Right atrial thrombus formation associated with central venous catheters utilization in hemodialysis patients. Intensive Care Med 2003;29:1829-32.

[148] Obrador GT, Levenson DJ. Spinal epidural abscess in hemodialysis patients: report of three cases and review of the literature. American journal of kidney diseases : the official journal of the National Kidney Foundation 1996;27:75-83.

[149] Hemmelgarn BR, Moist LM, Lok CE, et al. Prevention of dialysis catheter malfunction with recombinant tissue plasminogen activator. The New England journal of medicine 2011;364:303-12.

[150] Saad TF. Bacteremia associated with tunneled, cuffed hemodialysis catheters. American journal of kidney diseases : the official journal of the National Kidney Foundation 1999;34:1114-24.

[151] Lok CE, Stanley KE, Hux JE, Richardson R, Tobe SW, Conly J. Hemodialysis infection prevention with polysporin ointment. J Am Soc Nephrol 2003;14:169-79.

[152] Zhang J, Melhem M, Kassing W, et al. In vitro paclitaxel and radiation effects on the cell types responsible for vascular stenosis: a preliminary analysis. Blood Purif 2007;25:155-60.

[153] Mermel LA, Farr BM, Sherertz RJ, et al. Guidelines for the management of intravascular catheter-related infections. Clin Infect Dis 2001;32:1249-72.

[154] Capdevila JA, Segarra A, Planes AM, et al. Successful treatment of haemodialysis catheter-related sepsis without catheter removal. Nephrology, dialysis, transplantation : official publication of the European Dialysis and Transplant Association - European Renal Association 1993;8:231-4.

[155] Fernandez-Hidalgo N, Almirante B, Calleja R, et al. Antibiotic-lock therapy for longterm intravascular catheter-related bacteraemia: results of an open, noncomparative study. J Antimicrob Chemother 2006;57:1172-80.

[156] Vardhan A, Davies J, Daryanani I, Crowe A, McClelland P. Treatment of haemodialysis catheter-related infections. Nephrology, dialysis, transplantation : official publication of the European Dialysis and Transplant Association - European Renal Association 2002;17:1149-50. 
[157] Levin A, Mason AJ, Jindal KK, Fong IW, Goldstein MB. Prevention of hemodialysis subclavian vein catheter infections by topical povidone-iodine. Kidney international 1991;40:934-8.

[158] Sesso R, Barbosa D, Leme IL, et al. Staphylococcus aureus prophylaxis in hemodialysis patients using central venous catheter: effect of mupirocin ointment. Journal of the American Society of Nephrology : JASN 1998;9:1085-92.

[159] Johnson LB, Jose J, Yousif F, Pawlak J, Saravolatz LD. Prevalence of colonization with community-associated methicillin-resistant Staphylococcus aureus among endstage renal disease patients and healthcare workers. Infection control and hospital epidemiology : the official journal of the Society of Hospital Epidemiologists of America 2009;30:4-8.

[160] James MT, Conley J, Tonelli M, Manns BJ, MacRae J, Hemmelgarn BR. Meta-analysis: antibiotics for prophylaxis against hemodialysis catheter-related infections. Annals of internal medicine 2008;148:596-605.

[161] Yahav D, Rozen-Zvi B, Gafter-Gvili A, Leibovici L, Gafter U, Paul M. Antimicrobial lock solutions for the prevention of infections associated with intravascular catheters in patients undergoing hemodialysis: systematic review and metaanalysis of randomized, controlled trials. Clinical infectious diseases : an official publication of the Infectious Diseases Society of America 2008;47:83-93.

[162] Jaffer Y, Selby NM, Taal MW, Fluck RJ, McIntyre CW. A meta-analysis of hemodialysis catheter locking solutions in the prevention of catheter-related infection. American journal of kidney diseases : the official journal of the National Kidney Foundation 2008;51:233-41.

[163] Snaterse M, Ruger W, Scholte Op Reimer WJ, Lucas C. Antibiotic-based catheter lock solutions for prevention of catheter-related bloodstream infection: a systematic review of randomised controlled trials. The Journal of hospital infection 2010;75:111.

[164] Pervez A, Ahmed M, Ram S, et al. Antibiotic lock technique for prevention of cuffed tunnel catheter associated bacteremia. The journal of vascular access 2002;3:108-13.

[165] Landry DL, Braden GL, Gobeille SL, Haessler SD, Vaidya CK, Sweet SJ. Emergence of gentamicin-resistant bacteremia in hemodialysis patients receiving gentamicin lock catheter prophylaxis. Clinical journal of the American Society of Nephrology : CJASN 2010;5:1799-804.

[166] Diskin CJ, Stokes TJ, Jr., Pennell AT. Pharmacologic intervention to prevent hemodialysis vascular access thrombosis. Nephron 1993;64:1-26.

[167] Sreedhara R, Himmelfarb J, Lazarus JM, Hakim RM. Anti-platelet therapy in graft thrombosis: results of a prospective, randomized, double-blind study. Kidney Int 1994;45:1477-83.

[168] Schmitz PG, McCloud LK, Reikes ST, Leonard CL, Gellens ME. Prophylaxis of hemodialysis graft thrombosis with fish oil: double-blind, randomized, prospective trial. Journal of the American Society of Nephrology : JASN 2002;13:184-90.

[169] Gradzki R, Dhingra RK, Port FK, Roys E, Weitzel WF, Messana JM. Use of ACE inhibitors is associated with prolonged survival of arteriovenous grafts. American journal of kidney diseases : the official journal of the National Kidney Foundation 2001;38:1240-4.

[170] Saran R, Dykstra DM, Wolfe RA, Gillespie B, Held PJ, Young EW. Association between vascular access failure and the use of specific drugs: the Dialysis Outcomes and Practice Patterns Study (DOPPS). Am J Kidney Dis 2002;40:1255-63. 
[171] Dixon BS, Beck GJ, Vazquez MA, et al. Effect of dipyridamole plus aspirin on hemodialysis graft patency. N Engl J Med 2009;360:2191-201.

[172] Schmitz PG, McCloud LK, Reikes ST, Leonard CL, Gellens ME. Prophylaxis of hemodialysis graft thrombosis with fish oil: double-blind, randomized, prospective trial. J Am Soc Nephrol 2002;13:184-90.

[173] Lok CE, Allon M, Donnelly S, et al. Design of the fish oil inhibition of stenosis in hemodialysis grafts (FISH) study. Clin Trials 2007;4:357-67.

[174] Murthy SN, Obregon DF, Chattergoon NN, et al. Rosiglitazone reduces serum homocysteine levels, smooth muscle proliferation, and intimal hyperplasia in Sprague-Dawley rats fed a high methionine diet. Metabolism 2005;54:645-52.

[175] Takagi T, Yamamuro A, Tamita K, Katayama M, Morioka S. Thiazolidinedione treatment attenuates diffuse neointimal hyperplasia in restenotic lesions after coronary stent implantation in type 2 diabetic patients: an intravascular ultrasound study. J Cardiol 2005;45:139-47.

[176] Davies MG, Owens EL, Mason DP, et al. Effect of platelet-derived growth factor receptor-alpha and -beta blockade on flow-induced neointimal formation in endothelialized baboon vascular grafts. Circ Res 2000;86:779-86.

[177] Hausleiter J, Kastrati A, Mehilli J, et al. Randomized, double-blind, placebo-controlled trial of oral sirolimus for restenosis prevention in patients with in-stent restenosis: the Oral Sirolimus to Inhibit Recurrent In-stent Stenosis (OSIRIS) trial. Circulation 2004;110:790-5.

[178] Rutherford C, Martin W, Salame M, Carrier M, Anggard E, Ferns G. Substantial inhibition of neo-intimal response to balloon injury in the rat carotid artery using a combination of antibodies to platelet-derived growth factor-BB and basic fibroblast growth factor. Atherosclerosis 1997;130:45-51.

[179] Leppanen O, Rutanen J, Hiltunen MO, et al. Oral imatinib mesylate (STI571/gleevec) improves the efficacy of local intravascular vascular endothelial growth factor-C gene transfer in reducing neointimal growth in hypercholesterolemic rabbits. Circulation 2004;109:1140-6.

[180] Fareh J, Martel R, Kermani P, Leclerc G. Cellular effects of beta-particle delivery on vascular smooth muscle cells and endothelial cells: a dose-response study. Circulation 1999;99:1477-84.

[181] Rubin P, Williams JP, Riggs PN, et al. Cellular and molecular mechanisms of radiation inhibition of restenosis. Part I: role of the macrophage and platelet-derived growth factor. International journal of radiation oncology, biology, physics 1998;40:929-41.

[182] Sabate M, Serruys PW, van der Giessen WJ, et al. Geometric vascular remodeling after balloon angioplasty and beta-radiation therapy: A three-dimensional intravascular ultrasound study. Circulation 1999;100:1182-8.

[183] Mayberg MR, Luo Z, London S, Gajdusek C, Rasey JS. Radiation inhibition of intimal hyperplasia after arterial injury. Radiat Res 1995;142:212-20.

[184] Kelly BS, Narayana A, Heffelfinger SC, et al. External beam radiation attenuates venous neointimal hyperplasia in a pig model of arteriovenous polytetrafluoroethylene (PTFE) graft stenosis. International journal of radiation oncology, biology, physics 2002;54:263-9.

[185] Sun S, Beitler JJ, Ohki T, et al. Inhibitory effect of brachytherapy on intimal hyperplasia in arteriovenous fistula. The Journal of surgical research 2003;115:200-8. 
[186] Misra S, Bonan R, Pflederer T, Roy-Chaudhury P. BRAVO I: A pilot study of vascular brachytherapy in polytetrafluoroethylene dialysis access grafts. Kidney Int 2006;70:2006-13.

[187] Yu SY, Chiu JH, Yang SD, Hsu YC, Lui WY, Wu CW. Biological effect of far-infrared therapy on increasing skin microcirculation in rats. Photodermatology, Photoimmunology \& Photomedicine 2006;22:78-86.

[188] Akasaki Y, Miyata M, Eto H, et al. Repeated thermal therapy up-regulates endothelial nitric oxide synthase and augments angiogenesis in a mouse model of hindlimb ischemia. Circulation journal : official journal of the Japanese Circulation Society 2006;70:463-70.

[189] Ikeda Y, Biro S, Kamogawa Y, et al. Repeated thermal therapy upregulates arterial endothelial nitric oxide synthase expression in Syrian golden hamsters. Jpn Circ J 2001;65:434-8.

[190] Lin CC, Chang CF, Lai MY, Chen TW, Lee PC, Yang WC. Far-infrared therapy: a novel treatment to improve access blood flow and unassisted patency of arteriovenous fistula in hemodialysis patients. J Am Soc Nephrol 2007;18:985-92.

[191] Kelly B, Melhem M, Zhang J, et al. Perivascular paclitaxel wraps block arteriovenous graft stenosis in a pig model. Nephrol Dial Transplant 2006;21:2425-31.

[192] Melhem M, Kelly B, Zhang J, et al. Development of a local perivascular paclitaxel delivery system for hemodialysis vascular access dysfunction: polymer preparation and in vitro activity. Blood Purif 2006;24:289-98.

[193] Masaki T, Rathi R, Zentner G, et al. Inhibition of neointimal hyperplasia in vascular grafts by sustained perivascular delivery of paclitaxel. Kidney international 2004;66:2061-9.

[194] Paulson WD, Kipshidze N, Kipiani K, et al. Safety and Efficacy of Locally Eluted Sirolimus for Prolonging AV Graft Patency (PTFE Graft Plus Coll-R) First in Man Experience. Journal of the American Society of Nephrology 2008:252A.

[195] Nugent HM, Edelman ER. Endothelial implants provide long-term control of vascular repair in a porcine model of arterial injury. J Surg Res 2001;99:228-34.

[196] Nugent HM, Groothuis A, Seifert P, et al. Perivascular endothelial implants inhibit intimal hyperplasia in a model of arteriovenous fistulae: a safety and efficacy study in the pig. J Vasc Res 2002;39:524-33.

[197] Nugent HM, Rogers C, Edelman ER. Endothelial implants inhibit intimal hyperplasia after porcine angioplasty. Circ Res 1999;84:384-91.

[198] Nugent HM, Sjin RT, White D, et al. Adventitial endothelial implants reduce matrix metalloproteinase-2 expression and increase luminal diameter in porcine arteriovenous grafts. J Vasc Surg 2007;46:548-56.

[199] Hiltunen MO, Laitinen M, Turunen MP, et al. Intravascular adenovirus-mediated VEGF-C gene transfer reduces neointima formation in balloon-denuded rabbit aorta. Circulation 2000;102:2262-8.

[200] Burke SK, LaRochelle A, Mendenhall HV. Local Application of Recombinant Human Type I Pancreatic Elastase (PRT-201) to an Arteriovenous Fistula (AVF) Increase AVF Blood Flow in a Rabbit Model. Journal of the American Society of Nephrology 2008:252A.

[201] Haskal ZJ, Trerotola S, Dolmatch B, et al. Stent graft versus balloon angioplasty for failing dialysis-access grafts. The New England journal of medicine 2010;362:494503. 
[202] Maya ID, Allon M. Outcomes of thrombosed arteriovenous grafts: comparison of stents vs angioplasty. Kidney Int 2006;69:934-7.

[203] Chan MR, Bedi S, Sanchez RJ, et al. Stent placement versus angioplasty improves patency of arteriovenous grafts and blood flow of arteriovenous fistulae. Clin J Am Soc Nephrol 2008;3:699-705.

[204] Rotmans JI, Pattynama PM, Verhagen HJ, et al. Sirolimus-eluting stents to abolish intimal hyperplasia and improve flow in porcine arteriovenous grafts: a 4 -week follow-up study. Circulation 2005;111:1537-42.

[205] Haskal ZJ, Trerotola S, Dolmatch B, et al. Stent graft versus balloon angioplasty for failing dialysis-access grafts. N Engl J Med 2010;362:494-503.

[206] Krishnamoorthy MK, Banerjee RK, Wang Y, et al. Hemodynamic wall shear stress profiles influence the magnitude and pattern of stenosis in a pig AV fistula. Kidney Int 2008.

[207] Misra S, Woodrum DA, Homburger J, et al. Assessment of Wall Shear Stress Changes in Arteries and Veins of Arteriovenous Polytetrafluoroethylene Grafts Using Magnetic Resonance Imaging. Cardiovasc Intervent Radiol 2006.

[208] Nyberg SL, Hughes CB, Valenzuela YM, et al. Preliminary experience with a cuffed ePTFE graft for hemodialysis vascular access. Asaio J 2001;47:333-7.

[209] Tsoulfas G, Hertl M, Ko DS, et al. Long-term outcome of a cuffed expanded PTFE graft for hemodialysis vascular access. World journal of surgery 2008;32:1827-31.

[210] Sorom AJ, Hughes CB, McCarthy JT, et al. Prospective, randomized evaluation of a cuffed expanded polytetrafluoroethylene graft for hemodialysis vascular access. Surgery 2002;132:135-40.

[211] Ko PJ, Liu YH, Hung YN, Hsieh HC. Patency rates of cuffed and noncuffed extended polytetrafluoroethylene grafts in dialysis access: a prospective, randomized study. World journal of surgery 2009;33:846-51.

[212] Roy-Chaudhury P, Wang Y, Krishnamoorthy M, Dakin A. Optiflow: A Novel Anastomotic Conduit for Reducing AV Fistula Dysfunction. J Am Soc Nephrol 2008;19:253A.

[213] Falk A. Maintenance and salvage of arteriovenous fistulas. J Vasc Interv Radiol 2006;17:807-13.

[214] Yevzlin AS, Chan MR, Becker YT, Roy-Chaudhury P, Lee T, Becker BN. "Venopathy" at work: recasting neointimal hyperplasia in a new light. Transl Res 2010;156:216-25.

[215] Misra S, Fu AA, Anderson JL, et al. The rat femoral arteriovenous fistula model: increased expression of matrix metalloproteinase- 2 and -9 at the venous stenosis. J Vasc Interv Radiol 2008;19:587-94.

[216] Croatt AJ, Grande JP, Hernandez MC, Ackerman AW, Katusic ZS, Nath KA. Characterization of a model of an arteriovenous fistula in the rat: the effect of LNAME. Am J Pathol 2010;176:2530-41.

[217] Croatt AJ, Juncos JP, Hernandez MC, et al. Upregulation of Inflammation-Related Genes and Neointima Formation in Arteriovenous Fistula (AVF) Model in the Rat (Abstract). J Am Soc Nephrol 2008;19:252A. 


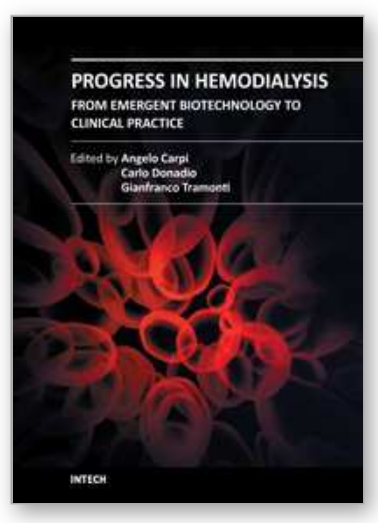

\section{Progress in Hemodialysis - From Emergent Biotechnology to Clinical Practice}

Edited by Prof. Angelo Carpi

ISBN 978-953-307-377-4

Hard cover, 444 pages

Publisher InTech

Published online 07, November, 2011

Published in print edition November, 2011

Hemodialysis (HD) represents the first successful long-term substitutive therapy with an artificial organ for severe failure of a vital organ. Because HD was started many decades ago, a book on HD may not appear to be up-to-date. Indeed, HD covers many basic and clinical aspects and this book reflects the rapid expansion of new and controversial aspects either in the biotechnological or in the clinical field. This book revises new technologies and therapeutic options to improve dialysis treatment of uremic patients. This book consists of three parts: modeling, methods and technique, prognosis and complications.

\section{How to reference}

In order to correctly reference this scholarly work, feel free to copy and paste the following:

Timmy Lee (2011). Hemodialysis Vascular Access Dysfunction, Progress in Hemodialysis - From Emergent Biotechnology to Clinical Practice, Prof. Angelo Carpi (Ed.), ISBN: 978-953-307-377-4, InTech, Available from: http://www.intechopen.com/books/progress-in-hemodialysis-from-emergent-biotechnology-to-clinicalpractice/hemodialysis-vascular-access-dysfunction

\section{INTECH}

open science | open minds

\section{InTech Europe}

University Campus STeP Ri

Slavka Krautzeka 83/A

51000 Rijeka, Croatia

Phone: +385 (51) 770447

Fax: +385 (51) 686166

www.intechopen.com

\section{InTech China}

Unit 405, Office Block, Hotel Equatorial Shanghai

No.65, Yan An Road (West), Shanghai, 200040, China

中国上海市延安西路65号上海国际贵都大饭店办公楼405单元

Phone: +86-21-62489820

Fax: $+86-21-62489821$ 
(C) 2011 The Author(s). Licensee IntechOpen. This is an open access article distributed under the terms of the Creative Commons Attribution 3.0 License, which permits unrestricted use, distribution, and reproduction in any medium, provided the original work is properly cited. 